A spectre is haunting Western Europe in the shape of growing American and Japanese domination of the strategic information technology (IT) sectors. Telecommunications is the one IT sector in which the position of the European Community (EC) countries has been most favourable. A dozen or so indigenous firms satisfy most of the requirements of the EC market and, taken as a whole, the Community represents 20 per cent of the world telecommunications market. This favourable position contrasts sharply with the situation in microelectronic components and data processing equipment, where the EC's position is becoming ever more precarious. The EC countries' traditional strength in the telecommunications sector stems from the fact that this sector is severely partitioned along national lines, a result of chauvinistic national procurement policies and a mosaic of nationally-specific technical standards. The most distinctive feature of the telecom sector is that a public agency, traditionally charged with sole responsibility for the operation and regulation of the network, dominates the market on the demand side, while a small 'ring' of private firms dominate the supply side. With the exception of defence and agriculture, no other sector has been so politicised and so protected.

Once a relatively stable sector in which institutional arrangements went unquestioned, the telecommunications sector faces radical change on three fronts: accelerating technological change; product markets that are becoming more internationalised; and institutional innovation in the shape of deregulation, at least in the US, the UK and Japan. Overall, the range and capacity of equipment attached to the network has steadily increased, with the result that the boundaries between telecommunications, data processing and office equipment are becoming less discernable. The technological advances of the past decade not only permit existing, 'first generation' services to be upgraded but, more importantly, they signal that a new telecommunications inf rastructure is emerging, capable of providing 'second' and 'third' generation services. [See Table 1] Converging technologies, together with the rise of new markets for equipment and services, have fashioned an environment that is radically different from the delays when the traditional regulatory regime was framed. Hence it is argued that 'we have now reached a point where technical, operational, demand and competitive changes have so dramatically emphasised the limitations of the existing regulatory framework ... that a new look at and approach to regulation becomes a necessity' [Little 1983].

Accelerating technological change confronts all the $\mathrm{EC}$ member countries in equal measure. But what is perhaps most striking is the fact that these 'imperatives' have met with quite different political responses in Britain, France and West Germany. This divergence constitutes the starting point of the underlying argument in this article: namely, that technology and markets do not of themselves dictate political or institutional forms, a point lost on functionalist proponents of 'natural' technological trajectories. However, the chief aim here is to chart the very different careers of the telecommunications sector in Britain and France.

\section{Britain: the Neo-Liberal Experiment}

Under the Thatcher government Britain's experience in telecommunications has been without precedent in Western Europe. In no other country has liberalisation proceeded so far. No other country has broken the state's monopoly of the telecommunications network. And no other country has privatised its national carrier. Liberalisation, which needs to be distinguished from privatisation, formally began in Britain in 1981, when the telecommunications function of the Post Office was hived off and invested in the newly formed British Telecom [BT]. Subsequently, the formerly rigid rules governing equipment sales and value-added network services [VANS] have been considerably liberalised. A rival company (Mercury, owned by Cable and Wireless) has been licensed to run a new telecommunications network. Two rival consortia (one led by BT, the other by Racal) have been authorised to operate cellular mobile radio networks. And, in 1984, BT was privatised and subjected to a new regulatory regime in the shape of the Office of Telecommunications [Oftel]. In conjunction these changes mean that Britain's regulatory system is among the most liberal in the world. Yet, radical as these changes seem in the European context, the Thatcher government could claim to be acting (in part) upon the neglected recommendations of the 1977 Carter Committee, which cailed for modest liberali- 


\begin{tabular}{|c|c|c|c|}
\hline Table 1 & Three Generations & Telecommications Services & \\
\hline Generation & $\begin{array}{c}\text { Telecommunication System } \\
\text { Required }\end{array}$ & Services & Availability \\
\hline First & $\begin{array}{l}\text { Existing analogue and narrow- } \\
\text { band digital telecommunications } \\
\text { networks }\end{array}$ & $\begin{array}{l}\text { - Telephony } \\
\text { - Telex } \\
\text { - Slow-speed data services } \\
\quad \text { (up to } 9.6 \mathrm{kbps} \text { ) } \\
\text { - Teletex } \\
\text { - Videotex }\end{array}$ & $\begin{array}{l}\text { - Traditional or in } \\
\text { process of } \\
\text { introduction }\end{array}$ \\
\hline Second & $\begin{array}{l}\text { Digital upgrading of existing } \\
\text { telecommunications networks } \\
\text { (e.g. ISDN) }\end{array}$ & $\begin{array}{l}\text { - High-speed data services } \\
\text { (n. } 64 \mathrm{kbps)} \\
\text { - Integrated services } \\
\text { (digital voice, data, text, } \\
\text { facsimile) } \\
\text { - Electronic mail } \\
\text { - Audio-graphic } \\
\text { conferencing }\end{array}$ & $\begin{array}{l}\text { - After introduction } \\
\text { of digital } \\
\text { switching and } \\
\text { digital local loops } \\
\text { in basic netorks }\end{array}$ \\
\hline Third & $\begin{array}{l}\text { Broadband transmission and } \\
\text { switching for at least } 2 \text { Mops } \\
\text { channel (e.g. fibre optics, } \\
\text { satellite-based, microwave) }\end{array}$ & $\begin{array}{l}\text { - Video-telephone } \\
\text { - Video-conferencing } \\
\text { - Very-high-speed data } \\
\text { communications } \\
\text { - Bulk document trans- } \\
\text { mission } \\
\text { - Two-way CATV }\end{array}$ & $\begin{array}{l}\text { - Satellite-based } \\
\text { system for } \\
\text { trial phase } \\
\text { - Large-scale } \\
\text { fibre-optics system } \\
\text { in early } \\
\text { conceptual stage }\end{array}$ \\
\hline
\end{tabular}

Source: Arthur D. Little, European Telecommunications - Strategic Issues and Opportunities for the Decade Ahead, Brussels, 1983 , p. 14

sation in terminal equipment and for the separation of posts and telecommunications. Even so, the government can also claim to have ventured way beyond the cautious Carter proposals by creating the nearest thing to a 'little America' in Europe. However, the British situation still falls far short of the apparent 'free-for-all' in the US.

A number of things have changed since the Labour government refused to act upon the Carter proposals. First and foremost, a radically different political party assumed office in 1979, committed, inter alia, to extending the sovereignty of the private market. Secondly, as more sophisticated equipment and services became available, especially in the form of private networks, business users became increasingly frustrated and more vocal about their inability to gain access to them quickly enough: and BT showed no apparent intention of introducing new equipment or services other than at its own convenience. Finally, the relationship between $\mathrm{BT}$ and its oligopolistic 'club' of suppliers - GEC, Plessey and STC - inspired less confidence as time wore on, especially as regards System X, Britain's family of digital switching systems, which has yet to win a major overseas order. Within this new conjuncture the Thatcher strategy had a number of aims:

(i) to create a more competitive market and a more dynamic supply industry;

(ii) to boost the economy as a whole by allowing business users to gain quicker access to a more advanced telecommunications infrastructure;

(iii) to use privatisation as a means of reducing the Public Sector Borrowing Requirement, which was inflated by BT because the latter did not have direct access to external financial markets.

Although Britain's basic telecommunications network is still burdened with huge tracts of obsolete equipment, and network modernisation still lags behind France and West Germany, deregulation has undoubtedly induced a spate of new services that are less developed or else unavailable in these continental 
countries. For example, with some 600 VANS (e.g. electronic mail, videotex networks) licensed in Britain since 1981, more than in the whole of the rest of Western Europe, Britain is sct to remain the largest European VANS market for some time. Similarly, cellular radio has already been introduced in Britain, whereas France and West Germany, being more concerned to use indigenous technology, have yet to install equivalent systems. However, while such services represent very real gains for business uscrs, there are also costs attached to a strategy that puts market-led demand before indigenous supply capacity. Cellular radio provides a perfect example of this dilemma. Because the Thatcher government set a premium on rapid deployment, the bulk of the technology and the associated equipment had to be imported from the US, Japan and Sweden. Britain, it seems, is more preparcd than France and West Germany to by-pass indigenous suppliers to gain access to advanced telecommunications.

Furthermore, foreign multinationals now perceive Britain to have the most attractive (i.e. liberal) telecommunications market in Western Europe and many of them, like Mitel, NEC, Northern Telecom and Rolm, have chosen Britain as their chief location in Europe. If this poses formidable problems for indigenous British firms, it is perfectly compatible with the Thatcher government's attempt to promote a cosmopolitan, rather than a purely domestic, form of re-industrialisation in Britain [Morgan and Sayer 1987].

It is already clear that deregulation is far from being a boon for all the actors in the telecommunications sector. Although BT itself did not foresee the extent of deregulation, particularly as regards network competition and privatisation, it has reacted with an aggression that few thought possible in such a bureaucratised organisation. Having fought - in vain - against the formation of Mercury, BT appears to have embraced privatisation with alacrity because it allowed management to run BT as a relatively autonomous company rather than as 'part of the economy'. Beginning in 1982, BT's once monolithic structure has been restructured into profit centres, and it has embarked on its self-proclaimed mission to become an international actor in information processing and office automation. To this end it is now far more willing - and able - to forge international alliances and to procure its equipment from suppliers other than GEC, Plessey and STC. So far BT's most dramatic decision on the latter front has been its move to source up to 20 per cent of its digital exchanges from Thorn Ericsson, much to the chagrin of the indigenous System X suppliers. Furthermore, BT is now hastily re-balancing its tariffs to reduce cross-subsidies between profitable business traffic and unprofitable residential services. As a result tariffs for major business users are decrcasing. Indeed BT now has the lowest business tariffs in Europe, a strategy designed to entice multinationals into establishing their telccommunications networks in Britain. These changes have becn facilitated by privatisation but, so far as BT is concerned, they were actually necessitated by Mercury's strategy of "crcaming off' business on BT's most profitable trunk and international routes.

As far as the othcr sectoral actors are concerned BT's traditional suppliers are opposed to aspects of the deregulatory programme, while the unions are against every bit of it. The principal supplier firms, GEC, Plessey and STC, had a long history of conflict among themselves prior to the current conflict between them and government over deregulation. For instance, as regards development of Systcm X, described by the Carter Committee as Britain's 'make-or-break' project in telecommunications, the Committee observed that thesc firms were not a 'natural team'. GEC and Plessey, for example, never fully endorsed STC as a legitimate collaborator in view of the latter's ITT parent. Bitter corporate feuding and protracted delays with System X eventually provoked BT, at the behest of the government, to threaten that some 30 per cent of digital exchange orders would be placed overseas unless a more effective arrangement was forthcoming. In the event, STC was obliged to withdraw from the System X programme in 1982 . albeit with exclusive contracts for the older (TXE4/4A) exchanges, and Plessey emerged as principal contractor with GEC as the sub-contractor. On the question of deregulation itself, the opposition from the traditional suppliers revolves around two issues in particular. Firstly, that Britain is liberalising its market without reciprocal arrangements elsewhere in Europe. And secondly, that privatisation is simply substituting a private monopoly for a public one, and that this provides BT with a greater opportunity to procure from overseas. Oftel judged that the first issue was a legitimate causc for concern, but could only recommond greater political action to promote liberalisation abroad. On the second issue Oftel offered little comfort, declaring that impcrfect competition was better than no competition. While Oftel recommended that BT should limit secondsourced digital exchanges to 20 per cent of the market for thrce years - a suggestion alreadt rejected by BT - it neverthelcss approved second sourcing as the only way to make competition a credible threat.

Unsettled and aggricved, the major suppliers count themselves among the victims of deregulation. They are now subject to a more hostile sectoral regime: BT, for so long a captive purchaser and therefore unable to excrcisc its latent power, is imposing much tougher procurement policies. For its part the government dismisses the suppliers' grievances as the necessary, if painful, costs of the transition to a more competitive supplier industry. As a response to the deregulatory 
wave the major suppliers have accelerated their search for corporate partners, in the US and in Europe, so as to strengthen their international position and extend their product range, especially in the computing side of information technology. Because of this more competitive environment, but also because of the perceived need to command greater economies of scale, GEC launched a major take-over bid for Plessey at the end of 1985.

Significantly, GEC has also tried to enlist trade union support in its opposition to BT's new procurement policies. When in 1985 GEC announced 900 redundancies it claimed that these were, in part, a direct consequence of BT's decision to 'go foreign' in the field of digital exchanges. If this was indeed calculated to accentuate 'buy British' demands from its unions so as to pressurise government, it succeeded on the former as conspicuously as it failed on the latter. Nevertheless, job security remains the key issue in trade union opposition to deregulation. BT's workforce, which is still 'over-manned' compared to the French DGT and the German Bundespost, suffered a net decline of 17,000 in the three years to 1985 and equally heavy losses will continue until 1990. Significant redundancies have been experienced too in each of BT's major supplier firms over the past five years. Telecommunications has been gripped by the jobless growth tendencies all too evident in other information technology sectors. Deregulation may be hastening the displacement of labour - though this is partly compensated for by additional employment within newly established, foreign firms - but it is neither the only nor the major cause. A more fundamental threat to employment is the transition from electro-mechanical exchanges, which are labourintensive on both production and maintenance, to digital exchanges which are associated with a numerically smaller, but higher skilled, workforce. Such 'technological' job loss would be difficult to stem without any deregulation. However, having failed to prevent deregulation, the trade unions have now placed their faith in the Labour Party, which is pledged to renationalise BT if returned to office. Fully aware of such a threat, the Thatcher government saw 'popular' shareholding as the best deterrent to renationalisation. While the Labour Party is still privately anxious on this score, the deterrent is not what it was: within six months of privatisation, BT's shareholders declined from $2.3 \mathrm{mn}$ to less than $1.7 \mathrm{mn}$ and, of these, private investors account for only 13.7 per cent of BT's total shares. This political prospectus means that the present institutional character of British telecommunications is by no means guaranteed a future.

Within the European context Britain's telecommunications sector has undergone a significant, and thus far unique, institutional transformation. Aided and abetted though it was by accelerating technological change and the advent of new markets, both of which compromised the traditional state monopoly, this transformation would not have been accomplished were it not for resolute political action on the part of the Thatcher government. Even so, we should not exaggerate the extent to which competition now reigns in Britain; not should we represent the Thatcher government as being hell bent on promoting competition or as having a unity of purpose. The truth is more prosaic. At every turn the government has been torn in two different, and somewhat contradictory, directions with respect to liberalisation and privatisation. Concerned to ensure that a 'privatised' BT commanded the best possible price, the government retreated from the more radical scenarios of liberalisation canvassed by some of its members. For instance, a proposal to dismember BT - along the lines of the divestiture of AT \& $\mathrm{T}$ - was considered and abruptly rejected, partly because it might have jeopardised the sale price, and partly because it would have diluted the 'flagship' role of BT vis-a-vis the British IT industry, an argument successfully deployed by BT itself. Little wonder that the British experiment is said to be inconsistent and contradictory, with the government's allegiance divided between BT's customers and its shareholders.

Notwithstanding the formation of Mercury, BT continues to occupy a formidable position in the British telecommunications sector. It possesses a de facto monopoly over the local network up to 1990 and, until then, Mercury will be its sole rival in longdistance and international services. Furthermore, BT has already established a large presence in markets - like large PABX's - that it did not address before 1983. And BT is already heavily involved in those technologies, like cellular mobile radio and cable television, that will eventually allow users to circumvent the local network. Regulation of BT is already stretching Oftel, whose powers are considerably less than those of the Federal Communication Commission in the US. While it is premature to assess how successful Oftel will be, this much is clear: regula tory policy will have to strike a balance between (i) the government's desire to see BT function as a 'flagship' for the pedestrian IT industry and (ii) its desire to placate critics who believe that BT is now more able to abuse its market power. Time alone will decide how this precarious balance is negotiated.

Finally, it is already apparent that the status of telecommunications in Britain is shifting so that it is less of a social, and more of a business service. Deregulation has fashioned a new configuration of winners and losers amongst suppliers and users. On the supply side, as we have seen, BT's traditional suppliers appear to be the major victims, and their inability to exploit the opportunities afforded by liberalisation has been a bitter disappointment to the government. There is clearly an enormous difference 
between deregulation in a context where one's indigenous suppliers are strong (as in the US) and a context (like Britain) where domestic suppliers are relatively weak. Deregulation, like free trade, privileges the strong, and it is no coincidence that many of the world's leading telecommunications firms have selected Britain as their chief European location. On the user side, the major beneficiaries of deregulation are large business users like financial institutions and the multinationals. However, small businesses and residential users are now experiencing higher charges so that large business users can enjoy discounts. Britain now has the dubious honour of having some of the highest charges in Western Europe for local calls, and the lowest charges for big business users [Morgan 1987]. This growing inequality a mong users is causing Oftel a good deal of anxiety; but it could have been foreseen because this is exactly what transpired in the US. Western Europe is now looking closely at the British, rather than at the US, deregulatory experience, because Britain is (or was) institutionally more akin to the continental telecommunications scene. At the moment, these countries seem less willing to cede public control over such a strategic sector as telecommunications. And some, like the FRG, appear far less willing to accept greater social inequality as the price to be paid for 'liberating' telecommunications.

\section{France: the Scope and Limits of a State-Led Strategy}

Until recently it seemed that France had embarked on a strategy that was the antithesis of the neo-liberal path being pursued in Britain. The most conspicuous divergence lay in the emphasis that France ascribed to a state-led strategy in telecommunications. In 1982 the two largest electronics groups, CGE and Thomson, were nationalised by the socialist government, and CGCT, the former ITT subsidiary, was added to the publicly-owned list in the following year. Then, in 1982, the Plan Filière Electronique, an a mbitious fiveyear plan for the electronics ind ustry, was launched in the hope of using strong sectors (like telecommunications) as a lever for the development of weaker sectors. Later, in 1983, CGE and Thomson initiated an asset swop - sanctioned by the government with the result that CIT-Alcatel, a subsidiary of CGE, assumed sole responsibility for their merged telecommunications activities, leaving Thomson to specialise in semiconductors, consumer electronics and military systems. The major rationale for these changes was the desire to provide the leading firms with sufficient public investment and economics of scale to enable them to act as national champions at home and abroad. However, without denying the logic behind these events, the fact remains that the telecommunications sector has been forced to contend with the internal upheavals of rationalisation, merger and a bewildering succession of industrial policy shifts, as well as with the external reverberations of deregulation in the US, Japan and Britain.

Before 1986 there was little or no public debate about liberalisation in France. Two factors in particular help to explain this state of affairs. Firstly, a bipartisan commitment to the traditional PTT model effectively removed liberalisation from the political agenda. Secondly, the DGT had incurred none of the criticisms that were levelled against the British Post Office in the 1970s. Rather, the DGT had earned itself a prodigious reputation by resolving 'la crise du téléphone'. Prior to the 1970s France had been afflicted by an embarrassing paradox: its grand technological a mbitions appeared somewhat ridiculous given the fact that it had one of the lowest telephone densities in the OECD. However, on the basis of a massive and belated public investment programme in the 1970s, the DGT transformed the French telephone network from an embarrassing oddity into one of the most efficient in Europe. At the same time, while Britain and the FRG struggled with digital exchanges in the 1970 s, France successfully managed to develop and install the world's first fully digital exchange. For these reasons the DGT had acquired something of a 'superstar' status in the industry and within the French administration [Bertho 1981].

While liberalisation was emerging on the British political agenda, the debate in France revolved around the implications of the influential Nora-Minc report [1978], which popularised the notion of 'telematics' (i.e. the convergence of computers and telecommunications). The unequivocal message of this report was that France should establish a position of international comparative advantage in telematics. Furthermore, since France would face a tremendous competitive challenge here from the likes of IBM, the French state authorities were enjoined to make 'unrestrained use of their trump card, which is to decree'. As a result, the pioneering role in this telematics scenario was alloted not to the market, but to the French state. The DGT eagerly embraced these proposals for a major state-led initiative for a number of reasons. In the first place, the DGT saw telematics as an opportunity to enhance its own authority and also as a means of achieving its objective of becoming an independent state-owned enterprise. Equally important, the DGT had become acutely conscious of the need for its suppliers to exploit new markets once the 1975-80 network expansion programme had peaked and, therefore, telematics seemed an ideal way forward in this respect. What eventually emerged from these pressures was the Plan Télématique of 1978 , inaugurating bold initiatives in such fields as videotex, teletext and an electronic directory, facsimile, a communications satellite and an experiment in optical fibres (at Biarritz) offering broadband facilities. 
With the launch of the telematics programme, the DGT propelled itself into activities that extended well beyond its traditional operations which, until then, had been confined to the telephone network. As if to affirm its new ambitions, the DGT set about estalishing a network of majority-owned subsidiaries, established under private law, and therefore outside the conventional restraints of the administration. These subsidiaries were seen as a flexible means of coping with rapidly changing markets and technology. Nevertheless, what the DGT did not sufficiently appreciate was that the telematics project did not lend itself to a state-led strategy in the way that network modernisation in the 1970 s so manifestly did. Indeed, the telematics venture was a good deal more precarious because of greater technological and market uncertainties. But, as important, whereas the DGT's remit clearly covered network development, the division of labour for telematics - between the DGT, equipment manufacturers and information vendors - was ill-defined and a source of conflict [Ergas 1983]. Furthermore, as a state-led strategy from 'above', it was not entirely surprising that the DGT's telematics programme encountered both market opposition (in the shape of demand constraints in facsimile, videotex and the 'minitel' electronics directory) and political opposition. Towards the end of the Giscard presidency the DGT incurred criticisms - from both left and right - of the authoritarian manner in which programmes were introduced without sufficient parliamentary debate and with too little respect for individual liberty. What best illustrated this authoritarianism was the experience in St Malo, where inhabitants were provided with free, but compulsory, minitels. Overall, and somewhat paradoxically perhaps, the apex of the DGT's power was reached in the late Giscard period, even though it appeared to have a greater stature under the socialists after 1981 .

With the advent of the Mitterrand Presidency in 1981 the position of the DGT changed in two important ways: (i) the DGT's profits began to be tapped for general budgetary purposes and (ii) the DGT was reluctantly obliged to finance parts of the filière electronique. If the stature of the DGT appeared to have grown under the socialists, its autonomy, as measured by its access to and control over funds, had been substantially eroded. However, a part from these changes (and those associated with nationalisation and mergers) the Mitterrand government endorsed most of the pre-existing telematics strategy. Indeed in 1982 the boldest programme of all was announced, namely, the decision to cable France with optical fibres for the transmission of voice, text and video. This daring, state-led programme was a fiercely contested affair in and beyond the DGT, largely as a result of the high cost of optical fibre cable. Well before the new Chirac government jettisoned the Plan
Cable, the DGT had already begun to abandon its original vision [Lacan 1987].

Despite such grand public ventures the Mitterrand government's faith in state-led growth palpably waned as time wore on. The austerity plans of 1982 and 1983 signalled the end of the government's early ambition to achicve 'growth-in-one-country'. Balance of payments problems and burgeoning deficits in leading nationalised firms like Thomson, CGCT and Bull, led to a backlash in favour of financial rectitude, particularly with respect to the nationalised sector. Thereafter the government became less enamoured of state-led initiatives and, instead, began to emphasise the merits of the firm, as in Mitterrand's classic 1984 declaration: 'c'est l'enterprise qui crée la richesse'. One of the major beneficiaries of this U-turn was the supposedly publicly-controlled CGE. Not only was it able to exploit its near monopoly supply position with the DGT, having successfully defeated the DGT's earlier opposition to the merger between Alcatel and Thomson, but it began to make corporate alliances without informing its political 'masters'. The alliance between CGE and ITT seems to have been presented to the government as a fait accompli. Another of CGE's alliances, with AT+T, has been awaiting political approval for nearly three years, largely because the deal initially involved $\mathrm{AT}+\mathrm{T}$ taking over the ailing CGCT and the Mitterrand regime, keen to promote European alliances, was reluctant to admit a US firm into the French market. Here, however, the socialist government faced a DGT which was more and more disposed towards $\mathrm{AT}+\mathrm{T}$, partly because $\mathrm{AT}+\mathrm{T}$ offered the best technology.

A further source of ignominy for the Mitterrand government concerned the employment front. Back in the euphoric days of 1981 the government was itself responsible for encouraging high, and thus fragile, expectations about potential employment growth in telecommunications. But with the precocious development of telecommunications in the 1970 s came over-capacity, a problem that has been accentuated with the merger between Alcatel and Thomson. In fact, employment has been falling since the late $1970 \mathrm{~s}$ as a result of strong productivity increases and the peaking of network expansion. In this context, from a trade-union perspective, the CFDT sees deregulation as a further threat to employment and is, therefore, totally opposed to it, and to any infringement of the DGT's monopoly. However, major redundancies have been declared at both Alcatel and Thomson, reinforcing a point made in the British context, namely, that jobs are under siege in telecommunications, irrespective of deregulation.

The experience of French telecommunications over the past 15 years illustrates the scope for, as well as the limits of, a state-led strategy. The DGT's successful reputation derives essentially from the 1970s: it 
depended upon a strong political commitment to a huge investment programme, involving public procurement in a protected national market for basic network equipment. However, the current decade is not so conducive to such a strategy because both markets and technology are less stable and, crucially, public-sector ordering is a declining proportion of total demand. Although the French socialists condemned deregulation in the US and Britain as politically motivated disruption, France had already discovered that it could not totally immunise itself from pressures outside its borders. For example, in response to transatlantic price-cutting, the DGT felt obliged to reduce its tariffs to North America, and it is now contemplating a 're-balancing' of its internal tariffs with a view to increasing local charges. This situation amounts to what the DGT once referred to as 'imported' de regulation. Well before the advent of a right-wing government the DGT was already considering some modest forms of deregulation, but it remained cautious and pragmatic. As its former director put it: "If no problems of hegemony are involved, we are prepared to deregulate. But if we see that the only consequence of deregulation is to allow the American computer industry to make profits at the expense of the French industry, then we regulate" (Financial Times, 1 February 1985).

In stark contrast to Britain, the DGT has sought European cooperation in the field of deregulation because it feels that unilateral moves in this direction might degenerate into an 'anarchic process' [Dondoux 1985].

The narrow victory of the neo-Gaullist RPR and the Giscardian UDF at the 1986 Parliamentary elections brought with it the possibility of more far-reaching steps towards denationalisation of the major telecommunications firms and deregulation of the telecommunications market. The RPR and UDF won the election on a programme which espoused both these objectives. Certainly, it seems that the new government will privatise Thomson and CGE. But leading figures in the Socialist Party (such as Fabius and Rocard) had been expressing support for limited denationalisation as a means of relieving the burden on an indebted state of raising the funds needed by the state-owned groups. It would seem that the 'dirigiste" tradition has lost its appeal to the major parties in France. However, it remains to be seen how far the RPR/UDF government will go in deregulating telecommunications. One year on from its electoral victory little real progress towards deregulation had been made beyond the sphere of rhetoric. Precedent suggests that a government of the French Right, with its much stronger sense of ind ust rial patriotism, would not pursue as radical a policy in this regard as the Thatcher government in Britain.

\section{Conclusions}

The very different careers of the public monopolies in Britain and France show that a good deal of political discretion accompanies even the most radical technological changes. In retrospect the public monopoly was breached with remarkable ease in Britain: its poor performance and its ponderous. bureaucratic procedures had left it with few allies. In contrast, the DGT had become something of a 'superstar' administration as a result of its crash modernisation programme in the 1970s. Even though this reputation became tarnished by the U-turn over the Plan Cable, the DGT could still point to a record of high productivity and commendable product innovation, with the result that it was seen as an 'instructive example of a flexible ... and innovative response by a public telecom entity to the challenges of a new era in the telecommunications field " Bruce et al. 1986]. The public monopolies in France and Germany may well be curtailed somewhat in the near future, but there is little prospect of them being broken to the same extent as in Britain. There is even less chance of them being privatised.

\section{References}

Little, A. D., 1983, European Telecommunications: Strategic Issues and Opportunities for the Decade Ahead. Brussels

Morgan, K. and A. Sayer, 1987, Microcircuits of Capital: 'Sunrise' Industr!' and Uneven Development, Polity Press. London

Morgan. K., 1987. 'Breaching the Monopoly: Telecoms and the State in Britain', Sussex Working Paper Series on Government-Industri Relations. No. 7

Bertho, C., 1981, Télégraphes er Téléphones, Le Livre de Poche, Paris

Ergas, H., 1983, Industrial Policy in France: The Case of Telecommunicanions, OECD. Paris

Lacan. J-F, 1987, 'La Fin du Plan Cable', $I e$ ' Monde, 13 January

Dondoux, J., 1985, L'Impact de la dereglementation internationale: le point de vue français: World Telecom Conference, London

Bruce, R., et al., 1986, From Telecommunications to Electronic Services, Butterworths, london 